\title{
Students' Preferences Between Blackboard Teaching and PowerPoint Presentations: A Cross-Sectional Survey
}

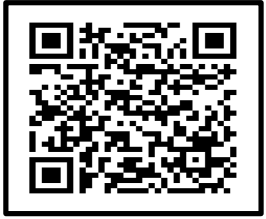

\section{AMOS MASIH*1, NIKHIL SETH², ADITYA SAXENA³, PRERNA BARUAH ${ }^{4}$}

INTRODUCTION: With evolution of technology, teachers have, or are shifting to various methods other that blackboard teaching (e.g. PowerPoint, Over Head Projectors, Integrated Learning, Online Apps, etc)

AIM: To assess Students' Preferences between blackboard teaching and PowerPoint Presentations among different university students in the city of Melbourne, Australia

MATERIALS AND METHOD: Data was collected using a pre-tested and pre-validated questionnaire and distributed online to students studying in various Universities in Melbourne, Australia. Statistical tests involved the Shapiro-Wilk test, Independent samples t-test, multivariate linear regression and the Pearson's correlation coefficient. The analysis was done using SPSS version 21.0.

RESULTS: There were a total of 827 complete responses (response rate: $82.6 \%$ ) and females formed a majority of the study population $(62 \%)$. Majority of the students (53.1\%) preferred PowerPoint presentations as compared to blackboard teaching (46.9\%), although the difference was minimal; responses of females was statistically significant $(\mathrm{p}=0.02)$. Significant differences $(\mathrm{p}=0.03)$ were also observed as $58.8 \%$ students considered blackboard teaching more interesting as compared to PowerPoint Lectures.

CONCLUSION: Students preferred PowerPoint presentations as compared to Blackboard teaching and the teachers should aim to make it as interesting as possible and allow student interaction in between.

KEYWORDS: Teaching, Learning, Students

\section{INTRODUCTION}

Across the globe, teaching is undergoing immense transformation. Teachers are moving from the traditional "chalk and talk" method to various other teaching modalities, which includes the use of PowerPoint, online assignments and use of online platforms for teaching-learning. In the classroom, however, most teachers are shifting to PowerPoint Presentations for their students, making it the most popular teaching aid amongst all. ${ }^{1}$

Classroom teaching has evolved over the years and has students belonging to various cultures, religion, family background all coming under one roof for learning. ${ }^{2}$ During a lecture, both the visual and auditory senses are used to absorb information and here assistance in the form of a visual aid is useful.3,4 It has been reported that approximately more than 400 million copies of PowerPoint are currently in circulation, and an estimated 20 to 30 million PowerPoint-based presentations are used to impart education in schools, Universities and various organizations. ${ }^{5}$

Despite its immense popularity and ease of use, researchers have stated that a PowerPoint presentation mostly serves as a one-way method of information dissemination and bores the student easily. The students feel ignored in lecture halls when their teacher focusses on the presentation and does not pay attention/ interact with the class. In the absence of a remote mouse and/or laser pointer, the teacher may not be able to leave the podium due to the need to advance to the next slide and this becomes monotonous for the students. ${ }^{6}$

A certain research concluded that PowerPoint fails in two key areas: increasing information transfer to our target (students) and improving what people think of your brand (and you). ${ }^{7}$ As a teacher, one has to adapt to good teaching technique so that there is maximum student learning occurring in the classroom. The present study hence, was designed to assess students' preferences between blackboard teaching and PowerPoint Presentations among different university students in the city of Melbourne, Australia.

\section{MATERIALS AND METHOD}

The present study was designed to be an online questionnaire based cross-sectional study and prior to 
its implementation, all necessary approvals and clearances were duly obtained from the respective authorities. The questionnaire was distributed to students of universities in Melbourne via a QR code/invitation link. The questionnaire contained 26 questions and was divided into 3 Sections. The first page of the questionnaire assured confidentiality of data, informed the study objectives and study that participation was purely voluntary. The consent to participate (inclusion criteria) was implied when the students agreed to answer the questionnaire and they had complete freedom to decline at any time. Access to data was only to the principal investigator and no personal details (e-mail id, phone number, name etc.) were asked. Among total submissions, if a student failed to answer $\geq 1$ question, it was excluded from the analysis. The study was conducted over a period of 3 months i.e. $1^{\text {st }}$ December, 2019 to $29^{\text {th }}$ February, 2020 and Data analysis included tests for normalcy Shapiro-Wilk test, Independent samples t-test and multivariate linear regression. Coded data was sent to the statistician so that confidentially of the data could be maintained. The analysis was done using SPSS version 21.0. ${ }^{8}$

\section{RESULTS}

It was observed that of a total of 1001 responses received, there were a total of 827 complete responses (response rate: $82.6 \%$ ) and females formed a majority of the study population $(514,62 \%)$ followed by males $(313,38 \%)$ and is described in figure 1.

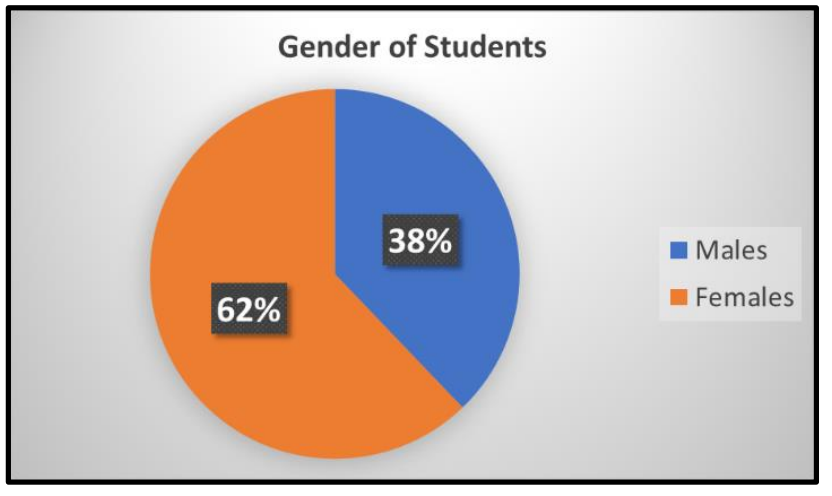

Figure 1. Distribution of the study population according to gender

Upon assessing student's preference towards the two teaching modalities assessed in the study, majority of the students (53.1\%) preferred PowerPoint presentations as compared to blackboard teaching (46.9\%), although the difference was minimal. The responses of females was found to be statistically significant $(\mathrm{p}=\mathrm{0.02})$. (Table 1$)$

\begin{tabular}{|c|c|c|c|c|}
\hline \multicolumn{5}{|c|}{ STUDENTS' PREFERENCES BETWEEN BLACKBOARD AND } \\
POWERPOINT TEACHING
\end{tabular}

Table 1. Students' preferences between blackboard and PowerPoint teaching. (* denotes a statistically significant response)

The responses to various questions by the students are depicted in table 2. It was observed that $51.5 \%$ students cityd that a blackboard helped them better understand the concepts and considered it to be the most interactive method (61.7\%), and this was found to be statistically significant in comparison to PowerPoint presentations $(\mathrm{p}=0.04)$. Significant differences $(\mathrm{p}=\mathrm{0.03})$ were also observed as $58.8 \%$ students considered blackboard lectures more interesting as compared to PowerPoint Lectures.

A multi variate logistic regression revealed that females gave a significant response towards PowerPoint as their preferred teaching method and is depicted in table 3 $(\mathrm{p}=.03)$

\section{DISCUSSION}

The results of the present study indicated that students belonging to various universities in Melbourne preferred PowerPoint teaching (53.1\%) as compared to the traditional blackboard teaching methodology, popularly known as the "Chalk and Talk" method. These results are in agreement to Shah $\mathrm{T}$ et al. who reported that $82.60 \%$ of physiotherapy students preferred the PowerPoint method of classroom teaching. 9

Literature has shown a stark contrast to the above results as various authors have reported the preference of blackboard teaching in comparison to PowerPoint teaching in the classroom. ${ }^{5,10,11,12}$ Such differences can be attributed to the teacher's way of teaching PowerPoint Presentations and making them more interactive by the use of discussions and animations. The PowerPoint 


\begin{tabular}{|c|c|c|c|c|}
\hline & BLACKBOARD & POWERPOINT & TOTAL & p VALUE \\
\hline $\begin{array}{l}\text { I understand } \\
\text { Lectures better }\end{array}$ & $501(60.5 \%)$ & $326(39 \cdot 5 \%)$ & $827(100 \%)$ & NS \\
\hline $\begin{array}{c}\text { It makes me } \\
\text { interested to attend } \\
\text { lectures } \\
\end{array}$ & $487(58.8 \%)$ & $340(41.2 \%)$ & $827(100 \%)$ & $0.03^{*}$ \\
\hline $\begin{array}{c}\text { Best Way to } \\
\text { Understand } \\
\text { Concepts } \\
\end{array}$ & $426(51.5 \%)$ & $401(48.5 \%)$ & $827(100 \%)$ & NS \\
\hline $\begin{array}{l}\text { Most Interactive } \\
\text { Method }\end{array}$ & $511(61.7 \%)$ & $316(38.3 \%)$ & $827(100 \%)$ & $0.04^{*}$ \\
\hline $\begin{array}{c}\text { Makes Entire } \\
\text { Classroom more } \\
\text { lively } \\
\end{array}$ & $406(49.1 \%)$ & $421(50.9 \%)$ & $827(100 \%)$ & NS \\
\hline $\begin{array}{l}\text { Helps us better in } \\
\text { Problem Solving } \\
\end{array}$ & $333(40.3 \%)$ & $494(59 \cdot 7 \%)$ & $827(100 \%)$ & NS \\
\hline $\begin{array}{c}\text { I get easily bored } \\
\text { while attending } \\
\text { Lectures }\end{array}$ & $201(24.3 \%)$ & $626(75 \cdot 7 \%)$ & $827(100 \%)$ & NS \\
\hline
\end{tabular}

Table 2. Responses of students' preferences to various questions present in the questionnaire. (* denotes a statistically significant response)

presentation also has an advantage that complex procedures can be explained by the use of embedded videos and pictures, provided that the teacher has sufficient knowledge of making such presentations.

Apart from a teacher's preference and style of teaching, there have been reports of varying preferences among students belonging to different courses. In a study conducted by Vikas $\mathrm{S}$ and colleagues ${ }^{13}$, it was reported that medical students have preferred PowerPoint whereas the dental students preferred the Chalkboard method although superiority of any lecture delivery method could not be established. Baxi SN and colleagues $^{12}$ reported an equal percentage of students preferred both teaching methodologies, while Chaudhary R et al. ${ }^{14}$ and Meo Sa et al. ${ }^{15}$ documented that he integrated (PowerPoint and chalkboard) method of teaching was found more suitable tool of teaching and learning than PowerPoint or chalkboard alone.

There are advantages as well as disadvantaged in both the methodologies. In respect to blackboard teaching, natural pauses and breaks (e. g. during writing or rubbing the blackboard) allowed students to follow the topic and take down the notes. The blackboard method also allows for greater spontaneity, flexibility and non linearity, does not get affected by broken glass [as compared to the now obsolete Overhead projectors (OHP)] and malfunctioning/defective projector lamps, loss of electricity, technical issues in projection and it does not need the classroom to be darkened. ${ }^{16}$

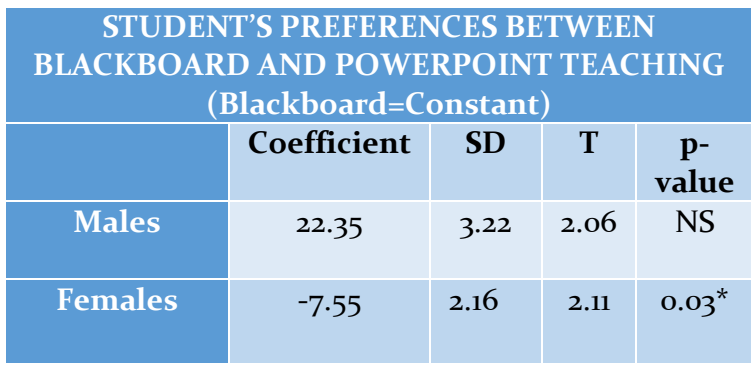

Table 3. Results of the Multivariate Logistic Regression. (* denotes a statistically significant response)

PowerPoint presentations, on the other hand saves the students from poor handwriting and a dirty blackboard. When used properly, It becomes more interesting and engaging for the students by incorporating videos, pictures and interactive sessions. Students mostly complained about the pace of such lectures (being too fast), Information overload in one slide and difficulties 
in seeing the slides due to use of smaller fonts. ${ }^{16}$

The present study is prone to certain limitations. The first is social desirability is of the respondents towards technology or the method currently incorporated by their teachers. Secondly, since this study was exploratory in nature, it did not classify students on the basis of the course pursued by them. Nevertheless, it is safe to city the results of the present study can be extrapolated and contribute to the existing scientific literature.

\section{CONCLUSION}

Based on the results of the present study, teachers are encouraged to continue teaching with PowerPoint. They are also advised to use innovative methods and have lively interactions so that students don't drift away from the subject and stay focussed on the topic being taught.

Acknowledgements: We thank all students who participated in the study for their time and consent to participate in the study.

\section{REFERENCES}

1. Prasad S, Roy B, Smith M. The art and science of presentation: electronic presentations. J Postgrad Med 2000;46:193-8.

2. Farah Naz F, Murad HS. Innovative Teaching Has a Positive Impact on the Performance of Diverse Students. SAGE Open 2017;7(4):1-8.

3. Sharma S, Shivalingesh KK, Thakar S, Sharma S, Chaudhary A, Dhanker K and Sharma M. Teaching innovation in the dental curriculum: student feedback and future aspects. Al Ameen J Med Sci 2019; 12(4):2259.

4. Sahu DR, Supe AN. The art and science of presentation: 35-mm slides. J Postgrad Med. 2000;46:280-5.

5. Shettigar D, Aranha P, Vargehese S. Power point Versus Chalk and Talk: Perception among Nursing Students an Exploratory Study. Asian J. Nursing Edu. and Research 2014;4(1): 131-5.
6. Voss D. PowerPoint in the Classroom; Is It Really Necessary?. Cell Biol Educ. 2004; 3(3):155-156.

7. Gloding N. Stop Using PowerPoint, Harvard University Says It's Damaging Your Brand And Your Company. Forbes. Online Article. https://www. freelancer.in/community/articles/stopusing-powerpoint-harvard-university-says-it-sdamaging-your-brand-and-your-company

[Last Assessed on $14^{\text {th }}$ March, 2020]

8. IBM Corp. Released 2010. IBM SPSS Statistics for Windows, Version 21.o. Armonk, NY: IBM Corp.

9. Shah T, Pate MA, Shah H. A comparative study on the teaching effectiveness of chalk \& talk versus microsoft powerpoint presentation. Int J Cur Res Rev. 2017;9(11):

http://dx.doi.org/10.7324/IJCRR.2017.9118

10. Gadicherla S, Babu RM. Comparison of Blackboard and PowerPoint Presentation in Teaching Biochemistry for MBBS Students. IJBAR 2018;:9(01):19-22. https://doi.org/10.7439/ijbar.v9i1.4551

11. Petimani MS, Adake P. Blackboard versus PowerPoint presentation: Students opinion in medical education. Int J Educ Psychol Res 2015;1:289-92 12. Baxi SN, Shah CJ, Parmar RD, Parmar, Tripathi CB. Student's perception of different teaching aids in a medical college. AJHPE. 2009;1(1):15-6.

13. Vikas S, Prerna U, Mushtaq A, Vijay M. PowerPoint or chalk and talk: Perceptions of medical students versus dental students in a medical college in India. Advances in Medical Education and Practice. 2012; 1:116. http://dx.doi.org/10.2147/AMEP.S12154

14. Chaudhary R, Dullo P, Gupta U. Attitude of 1st MBBS medical students about two different visual aids in physiology lectures. Pak Journal Physiology 2009;5(2):94-6.

15. Meo SA, Shahabuddin S, Al Masri AA, Ahmed SM, Aqil M, Answer MA, et al. Comparison of the impact of powerpoint and chalkboard in undergraduate medical teaching: an evidence based study. J Coll Physicians Surg Pak. 2013;23(1):47-50.

16. Seth V, Upadhyaya P, Ahmad M, Kumar V. Impact of Various Lecture Delivery Methods In Pharmacology. EXCLI Journal. 2010;9:96-101. 
Cite this article as:

Masih A, Seth N, Saxena A, Baruah P. Students' Preferences Between

Source of support: Nil, Conflict of interest: None declared

Blackboard Teaching and PowerPoint Presentations: A Cross-Sectional Survey.

Int Healthc Res J. 2020;4(3):64-68. https://doi.org/10.26440/IHRJ/0403.06350

AUTHOR AFFILIATIONS: ( ${ }^{*}$ Corresponding Author)

1. *Post Graduate Student, School of Public Health, Queensland University of Technology, Kelvin Groove Campus, Brisbane, Australia

2. Masters In Public Health Dentistry, Deakin University, Australia

3. BDS, Consultant Medical Surgeon, Melbourne Australia

4. MDS (Prosthodontics), Consultant Dental Surgeon, Melbourne, Australia

Contact corresponding author at: beta1osam[at]gmail[dot]com 